\title{
HIVEP1 wt Allele
}

National Cancer Institute

\section{Source}

National Cancer Institute. HIVEP1 wt Allele. NCI Thesaurus. Code C149345.

Human HIVEP1 wild-type allele is located in the vicinity of 6p24.1 and is approximately $157 \mathrm{~kb}$ in length. This allele, which encodes zinc finger protein 40 , is involved in the modulation of viral and cellular gene expression. 